\title{
An Ensemble of Pinanones from the Permanganate Oxidation of Myrtenal
}

\author{
Julia M. Clay,${ }^{\dagger}$ Dusan Hesek, ${ }^{\ddagger}$ Allen G. Oliver, ${ }^{\ddagger}$ \\ Mijoon Lee, ${ }^{\ddagger}$ Jed F. Fisher*‡ \\ ${ }^{\dagger}$ Lilly Research Laboratories, Eli Lilly \& Company, Indianapolis, Indiana 46285 \\ \& \\ ‡ Department of Chemistry \& Biochemistry, University of Notre Dame \\ Notre Dame IN 46556-5670
}

Supporting Material of 18 pp.:

S2, Fig. S1. ${ }^{1} \mathrm{H}$ NMR of the crude reaction mixture

S3, Fig. S2. Crystal data for 4

S4, Fig. S3. ${ }^{1} \mathrm{H}$ NMR of 4

S5, Fig. S4. ${ }^{13} \mathrm{C}$ NMR of 4

S6, Fig. S5. ${ }^{1} \mathrm{H}$ NMR of 5

S7, Fig. S6. ${ }^{13} \mathrm{C}$ NMR of 5

S8, Fig. S7. NOE analysis of 5

S10, Fig. S9. Enantiomeric ratio determination for 5

S10, Fig. S9. ${ }^{1} \mathrm{H}$ NMR of 6

S11, Fig. S10. ${ }^{13} \mathrm{C}$ NMR of 6

S12, Fig. S11. Crystal data for 7

S13 \& S14, Figs. S12 \& S13. ${ }^{1} \mathrm{H}$ NMR of 7

S15 \& S16, Figs. S14 \& S15. ${ }^{13} \mathrm{C}$ NMR of 7

S17, Fig. S16. ${ }^{1} \mathrm{H}$ NMR of 8

S18, Fig. S17. ${ }^{13} \mathrm{C}$ NMR of 8

*jfisher1@nd.edu 


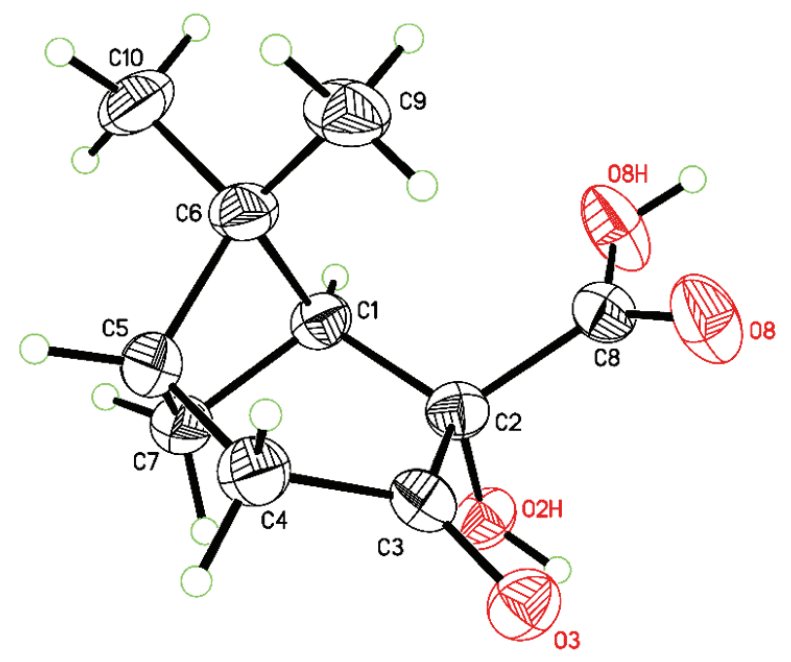

Figure S2. Atomic displacement plot of compound 4. Displacement ellipsoids depicted at $50 \%$ probability and hydrogen atoms as spheres of arbitrary radius.

Crystallographic analysis gives the relative configuration of $\mathbf{4}$.

\begin{tabular}{|c|c|}
\hline Identification code & Compound 4 \\
\hline Empirical formula & $\mathrm{C}_{10} \mathrm{H}_{14} \mathrm{O}_{4}$ \\
\hline Formula weight & 198.21 \\
\hline Temperature & $158(2) \mathrm{K}$ \\
\hline Wavelength & $0.71070 \AA$ \\
\hline Crystal system & Orthorhombic \\
\hline Space group & $\mathrm{P} 22_{1} 2_{1}$ \\
\hline \multirow[t]{6}{*}{ Unit cell dimensions } & $a=6.968(5) \AA$ \\
\hline & $b=8.073(5) \AA$ \\
\hline & $c=17.744(10) \AA$ \\
\hline & $\alpha=90^{\circ}$ \\
\hline & $\beta=90^{\circ}$ \\
\hline & $\gamma=90^{\circ}$ \\
\hline Volume & $998.1(11) \AA^{3}$ \\
\hline Z & 2 \\
\hline Density (calculated) & $1.319 \mathrm{~g} . \mathrm{cm}^{-3}$ \\
\hline Absorption coefficient $(\mu)$ & $0.102 \mathrm{~mm}^{-1}$ \\
\hline $\mathrm{F}(000)$ & 424 \\
\hline Crystal color, habit & colorless, prism \\
\hline Crystal size & $0.42 \times 0.2 \times 0.1 \mathrm{~mm}^{3}$ \\
\hline$\theta$ range for data collection & 5.18 to $26.43^{\circ}$ \\
\hline Index ranges & $0 \leq \mathrm{h} \leq 8,0 \leq \mathrm{k} \leq 10,0 \leq 1 \leq 22$ \\
\hline Reflections collected & 1140 \\
\hline Independent reflections & $1140\left[\mathrm{R}_{\mathrm{int}}=0.0000\right]$ \\
\hline Absorption correction & None \\
\hline Refinement method & Full-matrix least-squares on $\mathrm{F}^{2}$ \\
\hline Data / restraints / parameters & $1140 / 0 / 127$ \\
\hline Goodness-of-fit on $\mathrm{F}^{2}$ & 1.089 \\
\hline Final $R$ indices $[I>2 \sigma(I)]$ & $\mathrm{R}_{1}=0.0557, \mathrm{wR}_{2}=0.1427$ \\
\hline $\mathrm{R}$ indices (all data) & $\mathrm{R}_{1}=0.0648, \mathrm{wR}_{2}=0.1515$ \\
\hline Absolute structure parameter & $-1.84(275)$ \\
\hline Largest diff. peak and hole & 0.269 and $-0.238 \mathrm{e}^{-} . \AA^{-3}$ \\
\hline
\end{tabular}



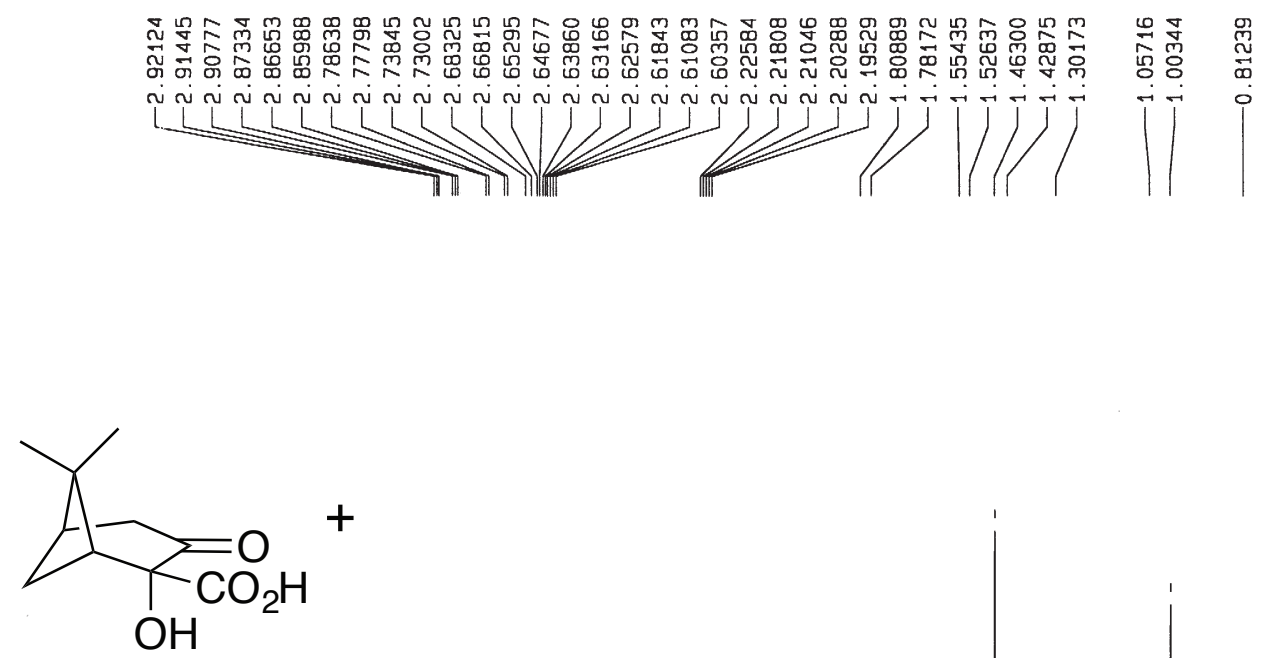

4

$\mathrm{CDCl}_{3^{\prime}} 400 \mathrm{MHz}$

Fig. S3.

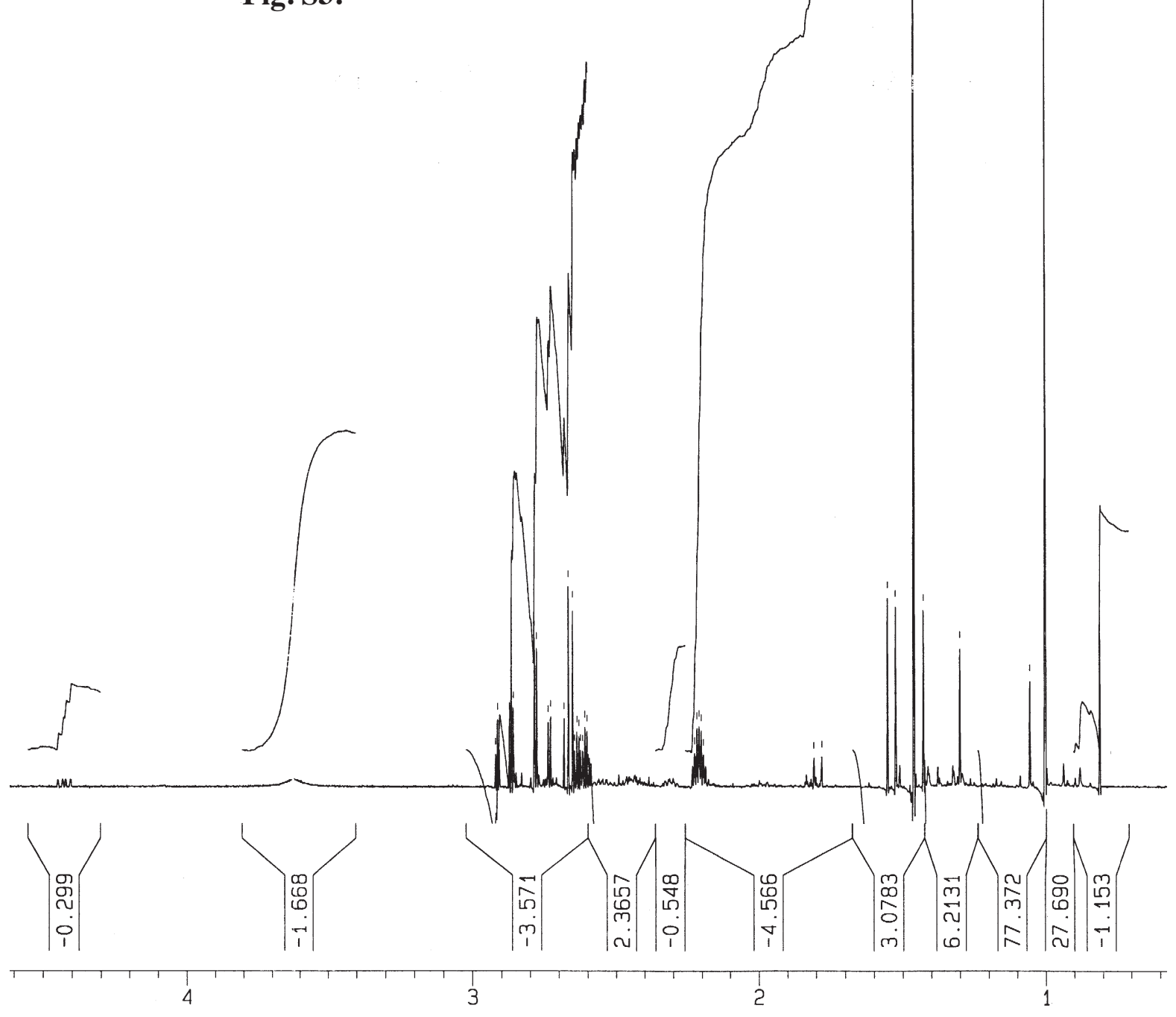

The impurity evident in this ${ }^{1} \mathrm{H}$ NMR spectrum of $\mathbf{4}$ is its decarboxylation product, 8 . 


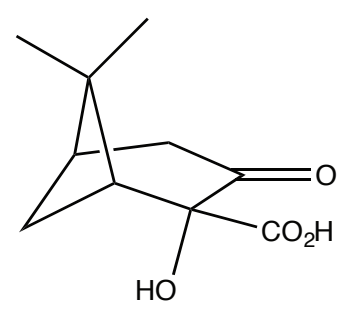

4
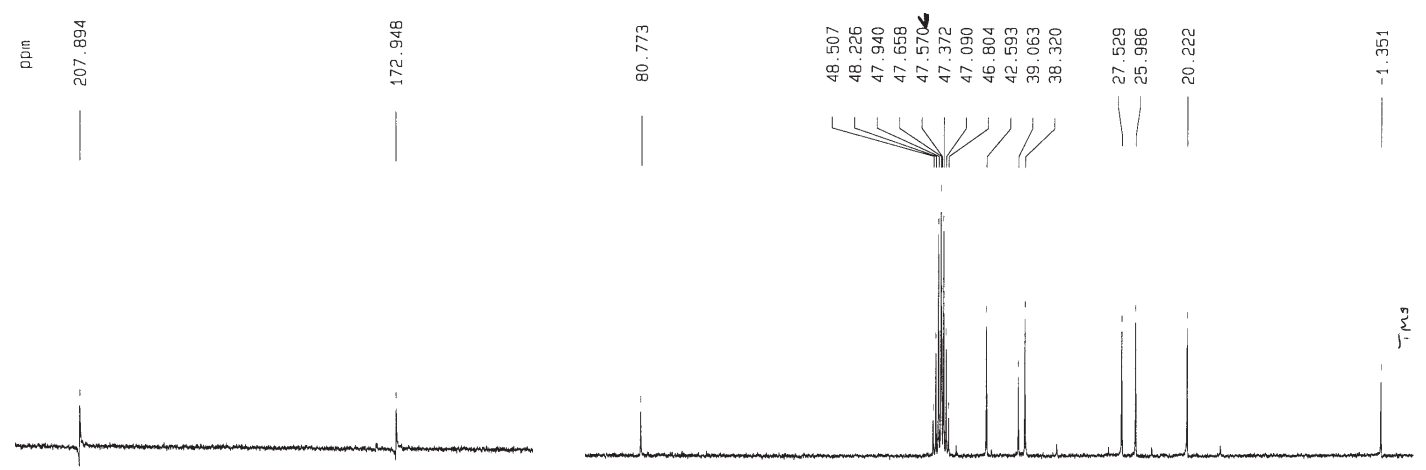

$\mathrm{CD}_{3} \mathrm{OD}$

$75 \mathrm{MHz}$
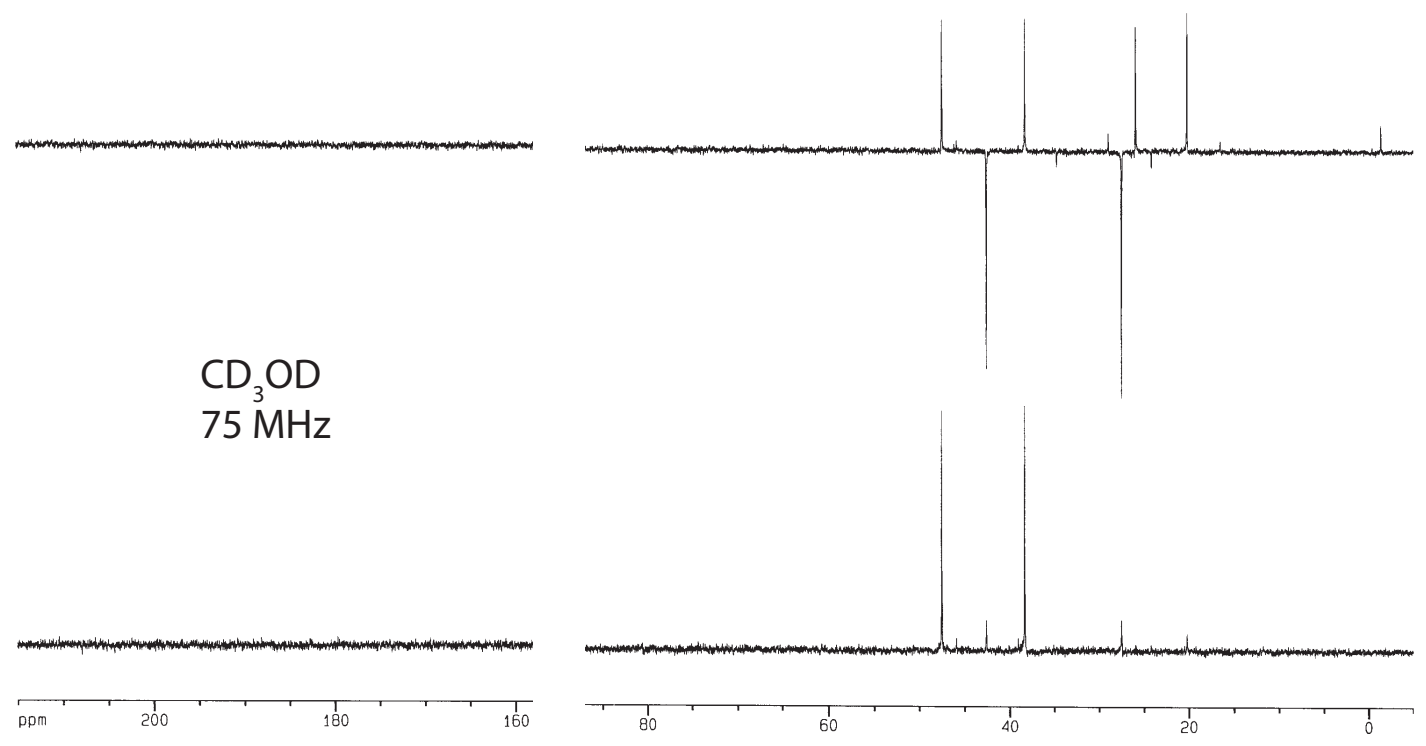

Fig. S4. ${ }^{13} \mathrm{C}$ NMR of 4 


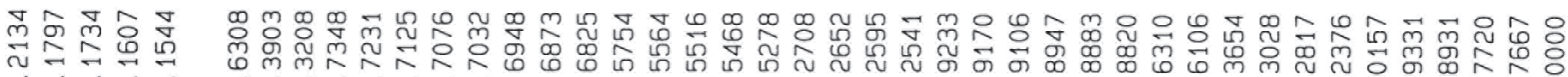
$\nabla \dot{\nabla} \nabla$ H
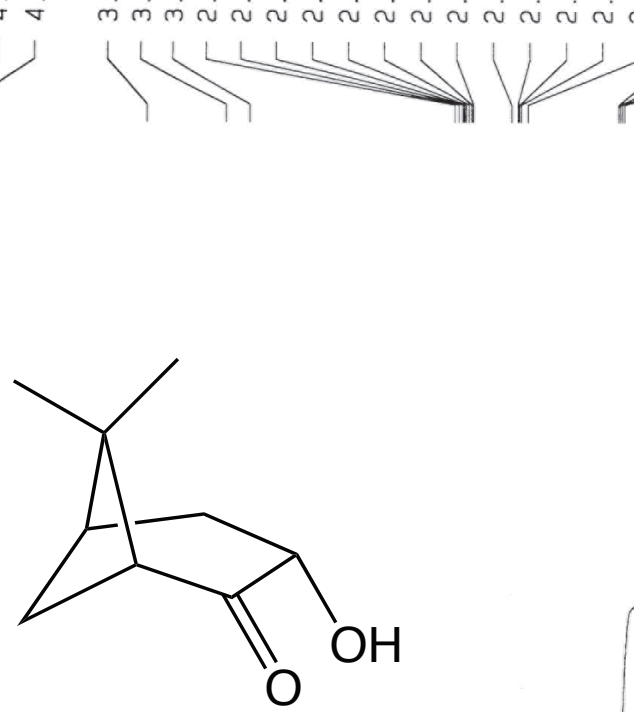

5

$\mathrm{CDCl}_{3^{\prime}}, 400 \mathrm{MHz}$

Fig. 55 .
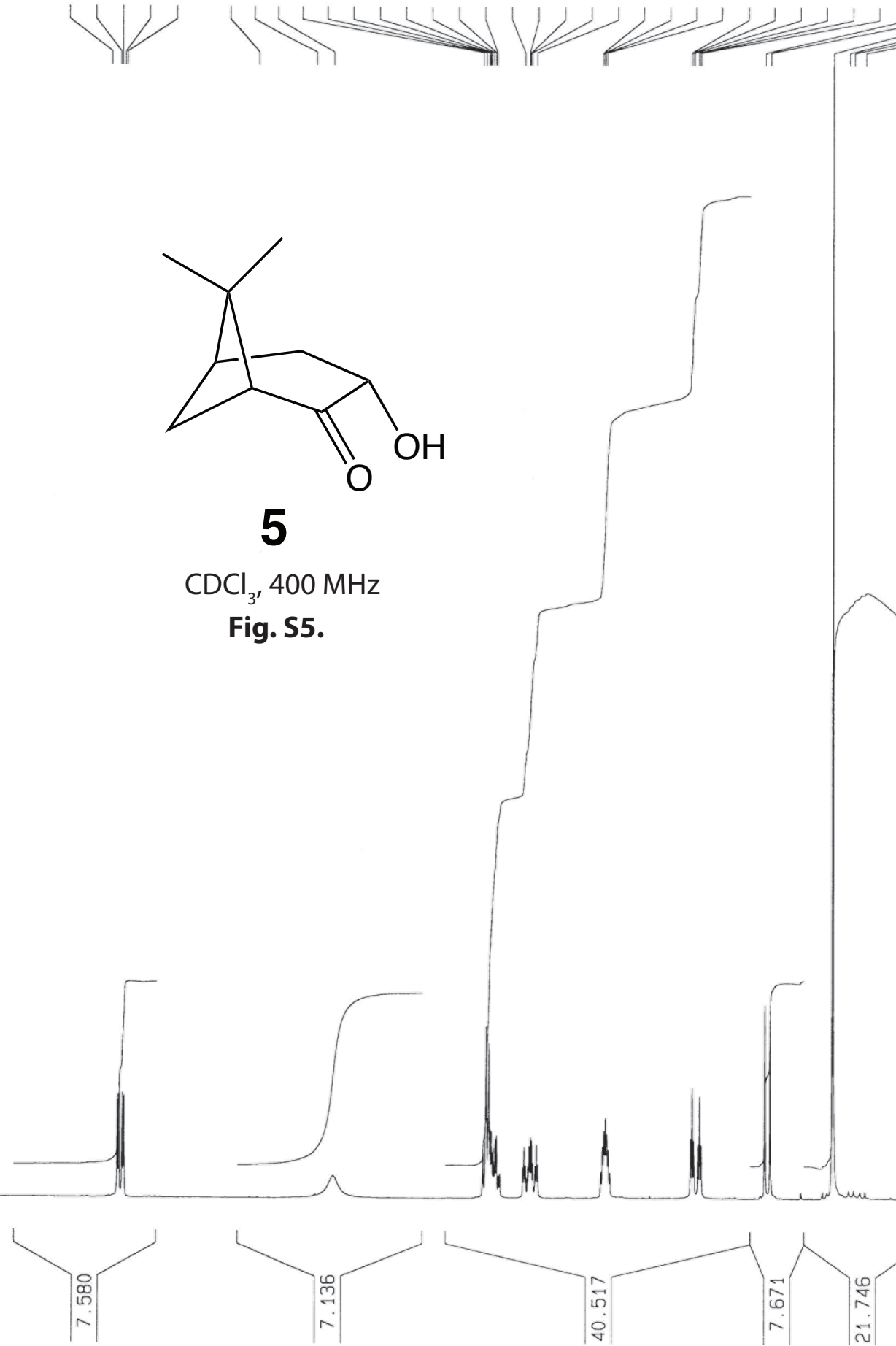


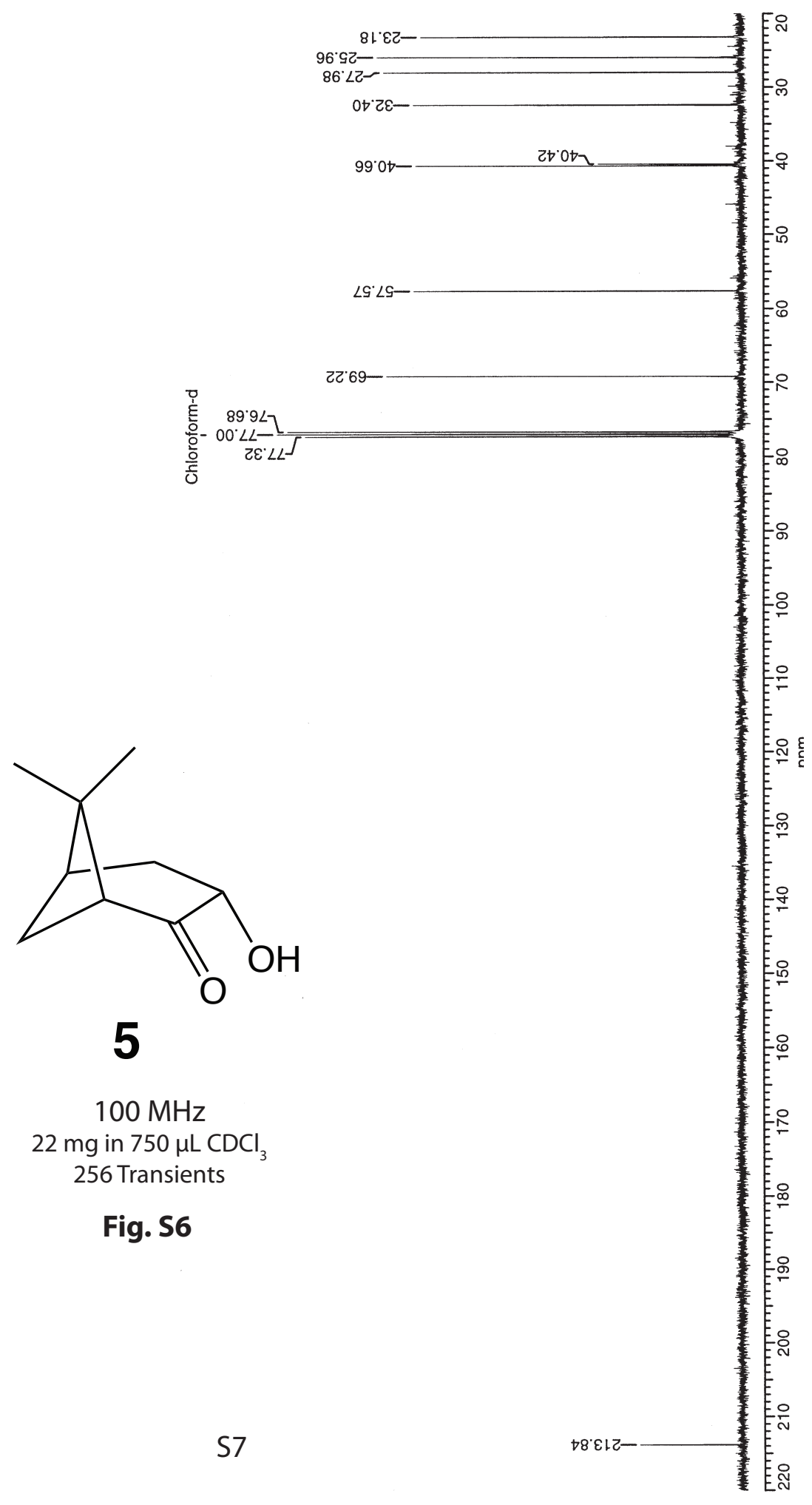



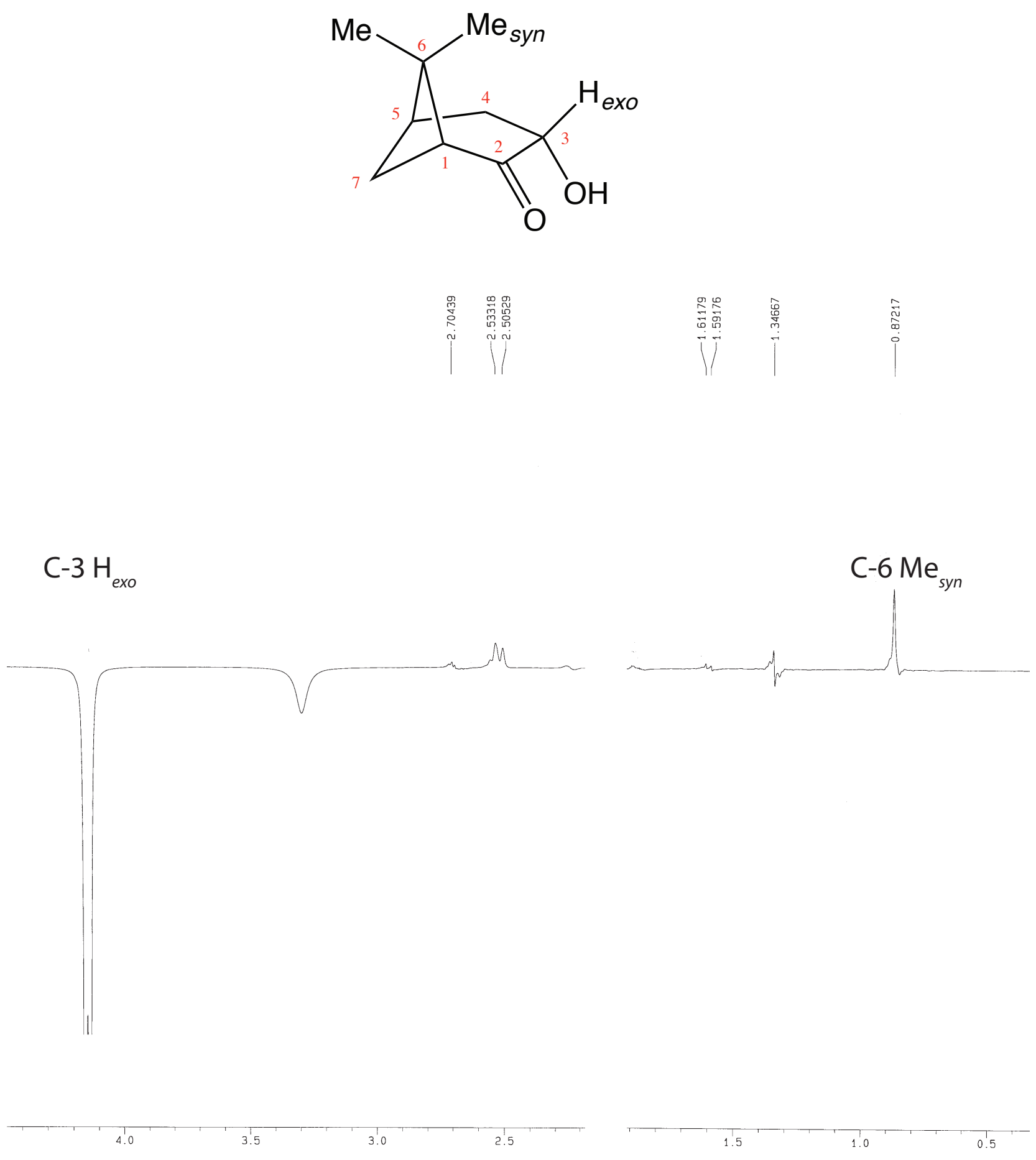

Figure S7. This NOE (DPFGSE) spectrum is representative of the NOE data used for the assignment of the relative configuration of the alcohol at C-3 of 5. Irradiation of the $3-\mathrm{CH}$ at $\delta 4.16$ exerts an NOE effect on the more shielded methyl resonance at C-6. The C-6 $\mathrm{Me}_{s y n}$ of pinanes is always the more shielded methyl resonance. ${ }^{12}$ 


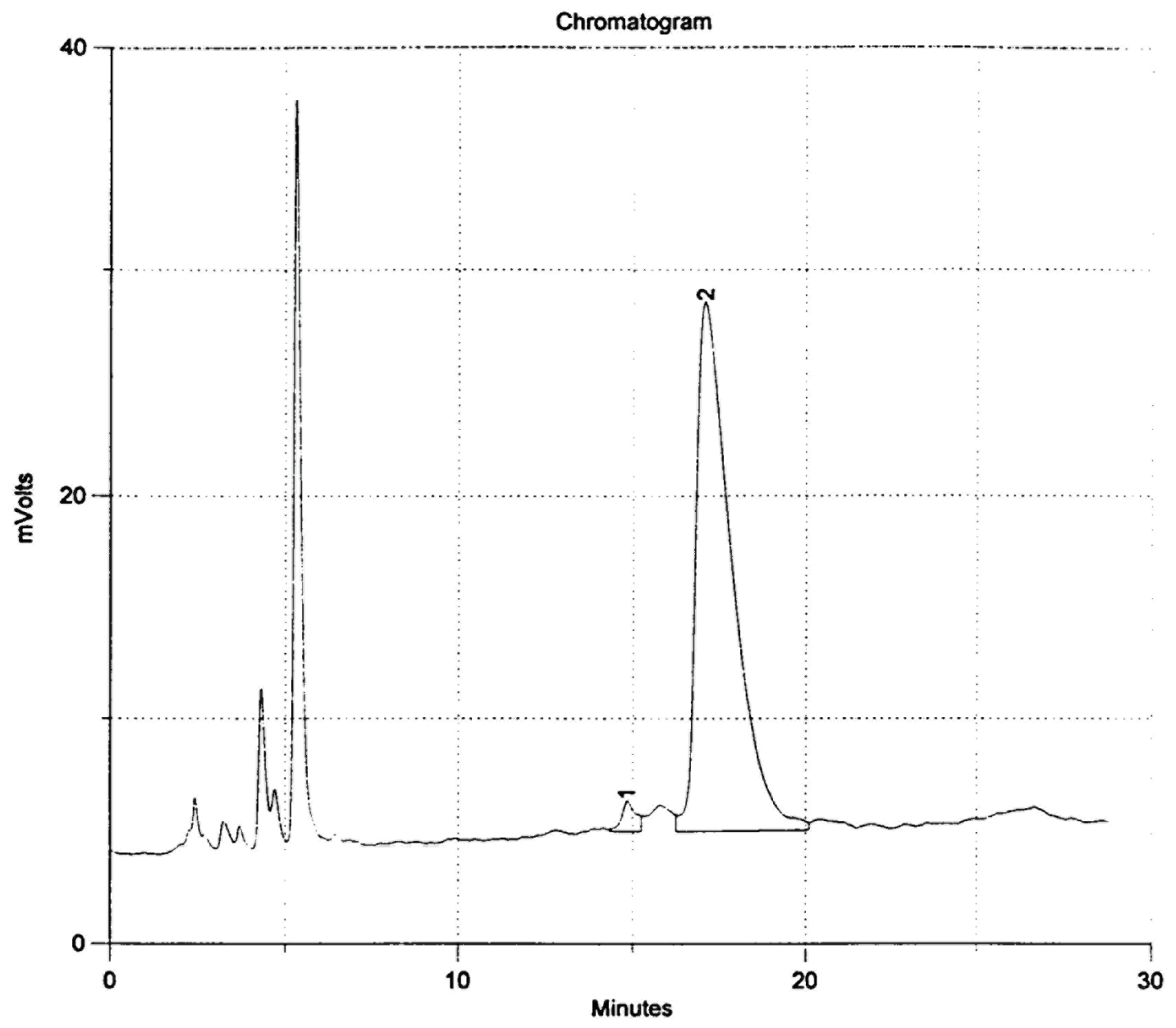

Fig. S8. Chiral-support chromatography evaluation of the enantiomeric ratio of 5 . Column conditions: $0.46 \times 25 \mathrm{~cm}(R, R)$-Whelko column using a 98:2 heptane/2-propanol mobile phase at $35^{\circ} \mathrm{C}$; flow rate $1.0 \mathrm{~mL} / \mathrm{min} ; 10 \mu \mathrm{L}$ injection. Area\% analysis for the $t_{\mathrm{R}}=14.8$ min peak of (+)-5 is $2.2 \%$, and for the $t_{\mathrm{R}}=17.1$ min peak (-)-5 is $97.8 \%$. The identity for the $t_{\mathrm{R}}=14.8 \mathrm{~min}$ peak is made from an authentic sample. This analysis is interpreted as an enantiomeric ratio of no less than 97:3. 


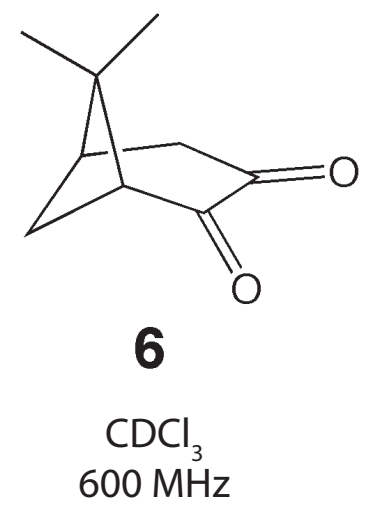

Fig. S9.

S10 
Fig. S10.

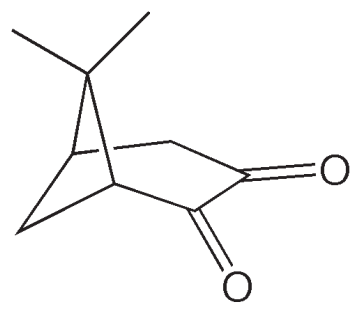

6

Dione 67 Multidept

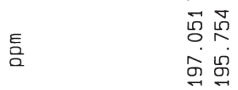

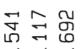

송

员

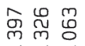

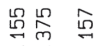

VI

भं $\vec{\nabla} \dot{m}$

㝏

$\mid$
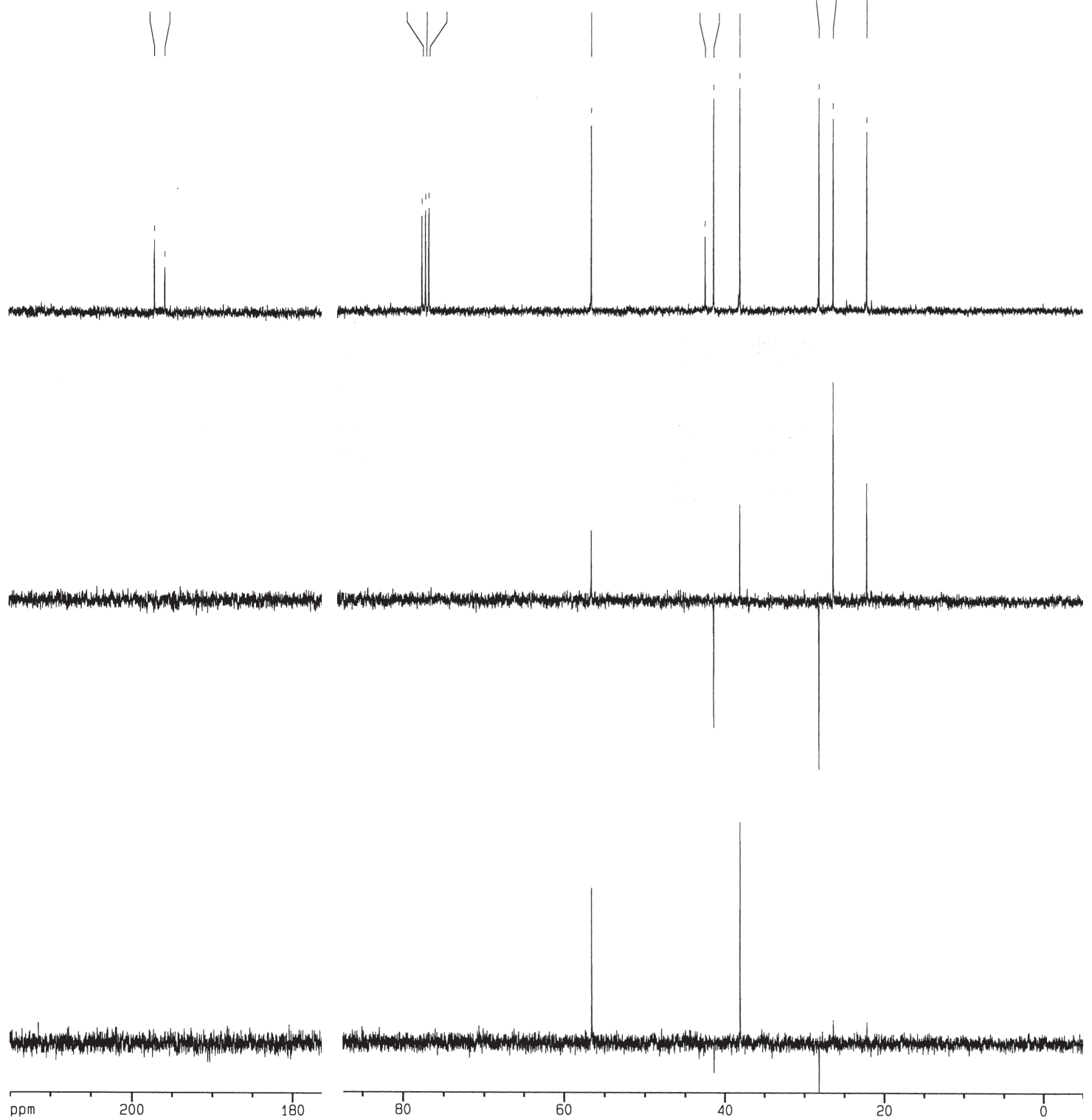


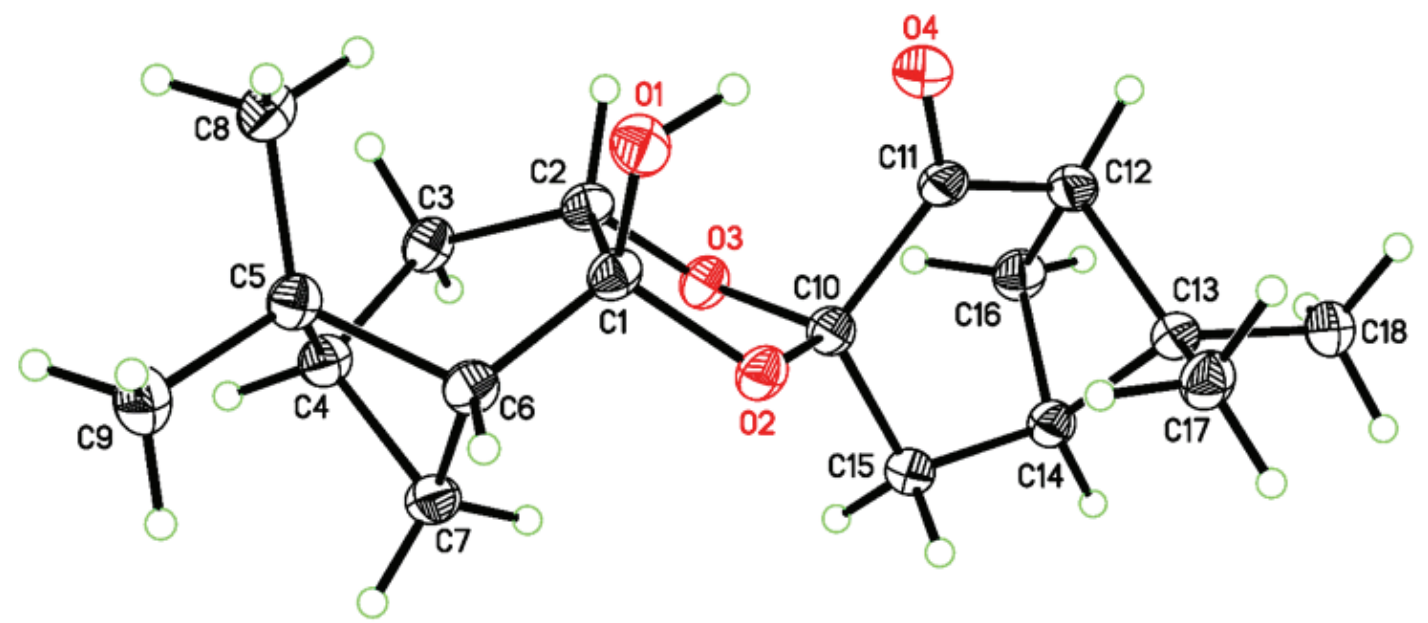

Figure S11. Atomic displacement plot of compound 7. Displacement ellipsoids depicted at 50\% probability and hydrogen atoms as spheres of arbitrary radius.

Crystallographic analysis gives the absolute configuration of $\mathbf{7}$.

Volume

\begin{tabular}{|c|c|}
\hline Identification code & Compound 7 \\
\hline Empirical formula & $\mathrm{C}_{18} \mathrm{H}_{26} \mathrm{O}_{4}$ \\
\hline Formula weight & 306.39 \\
\hline Temperature & $120(2) \mathrm{K}$ \\
\hline Wavelength & $1.54184 \AA$ \\
\hline Crystal system & Orthorhombic \\
\hline Space group & $\mathrm{P} 22_{1} 2_{1}$ \\
\hline \multirow[t]{6}{*}{ Unit cell dimensions } & $a=9.4198(2) \AA$ \\
\hline & $b=9.7083(3) \AA$ \\
\hline & $c=17.1134(4) \AA$ \\
\hline & $\alpha=90^{\circ}$ \\
\hline & $\beta=90^{\circ}$ \\
\hline & $\gamma=90^{\circ}$ \\
\hline Volume & $1565.02(7) \AA^{3}$ \\
\hline $\mathrm{Z}$ & 4 \\
\hline Density (calculated) & $1.300 \mathrm{~g} . \mathrm{cm}^{-3}$ \\
\hline Absorption coefficient $(\mu)$ & $0.729 \mathrm{~mm}^{-1}$ \\
\hline $\mathrm{F}(000)$ & 664 \\
\hline Crystal color, habit & colorless, rod \\
\hline Crystal size & $0.160 \times 0.110 \times 0.090 \mathrm{~mm}^{3}$ \\
\hline$\theta$ range for data collection & 5.169 to $72.069^{\circ}$ \\
\hline Index ranges & $-11 \leq \mathrm{h} \leq 10,-11 \leq \mathrm{k} \leq 11,-21 \leq 1 \leq 20$ \\
\hline Reflections collected & 21286 \\
\hline Independent reflections & $3072\left[\mathrm{R}_{\mathrm{int}}=0.0371\right]$ \\
\hline Completeness to $\theta=67.679^{\circ}$ & $100.0 \%$ \\
\hline Absorption correction & Semi-empirical from equivalents \\
\hline Max. and min. transmission & 0.9288 and 0.8433 \\
\hline Refinement method & Full-matrix least-squares on $\mathrm{F}^{2}$ \\
\hline Data / restraints / parameters & $3072 / 0 / 207$ \\
\hline Goodness-of-fit on $\mathrm{F}^{2}$ & 1.066 \\
\hline Final $R$ indices $[I>2 \sigma(I)]$ & $\mathrm{R}_{1}=0.0289, \mathrm{wR}_{2}=0.0738$ \\
\hline $\mathrm{R}$ indices (all data) & $\mathrm{R}_{1}=0.0294, \mathrm{wR}_{2}=0.0744$ \\
\hline \multicolumn{2}{|c|}{ Absolute structure parameter $0.03(6)$} \\
\hline Extinction coefficient & $\mathrm{n} / \mathrm{a}$ \\
\hline Largest diff. peak and hole & 0.178 and $-0.192 \mathrm{e}^{-} . \AA^{-3}$ \\
\hline
\end{tabular}




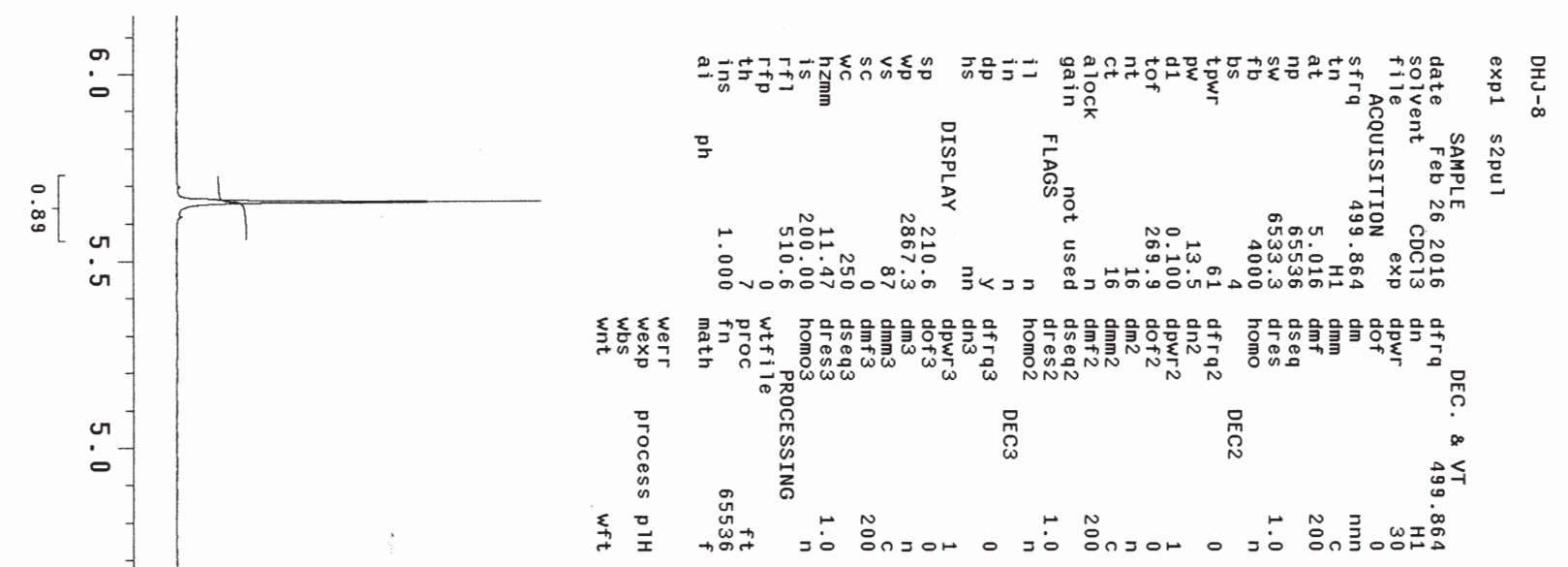

Fig. S12

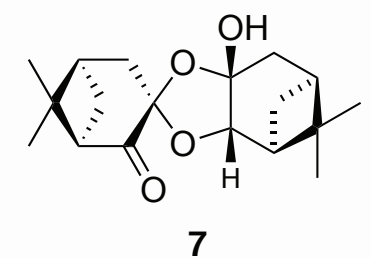

${ }^{1} \mathrm{H} N M R$

$\mathrm{CDCl}_{3}, 500 \mathrm{MHz}$

S13 
Fig. S13.

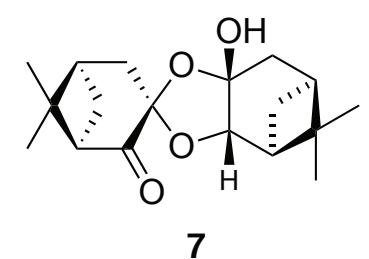

$\mathrm{CDCl}_{3}, 500 \mathrm{MHz}$

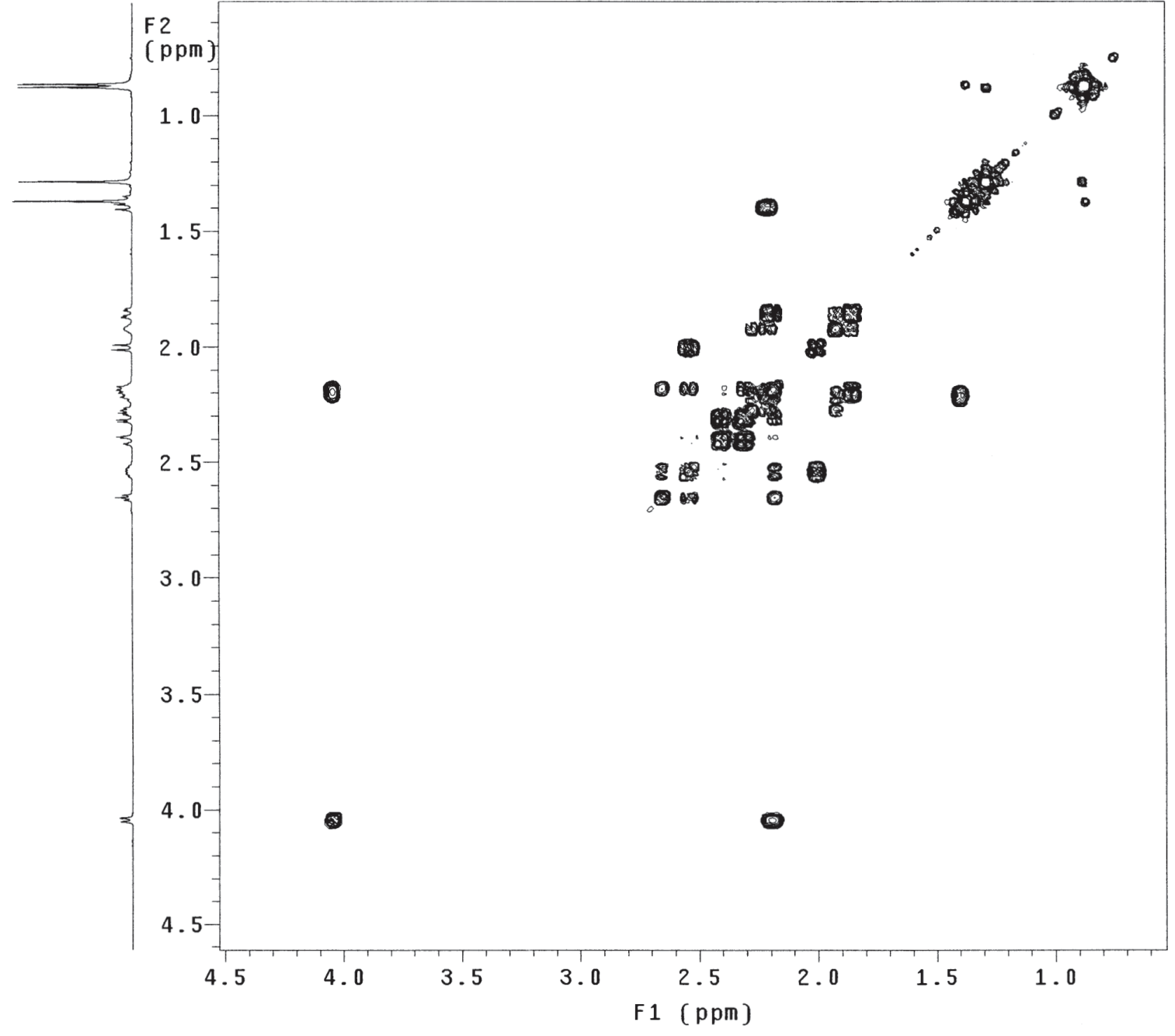




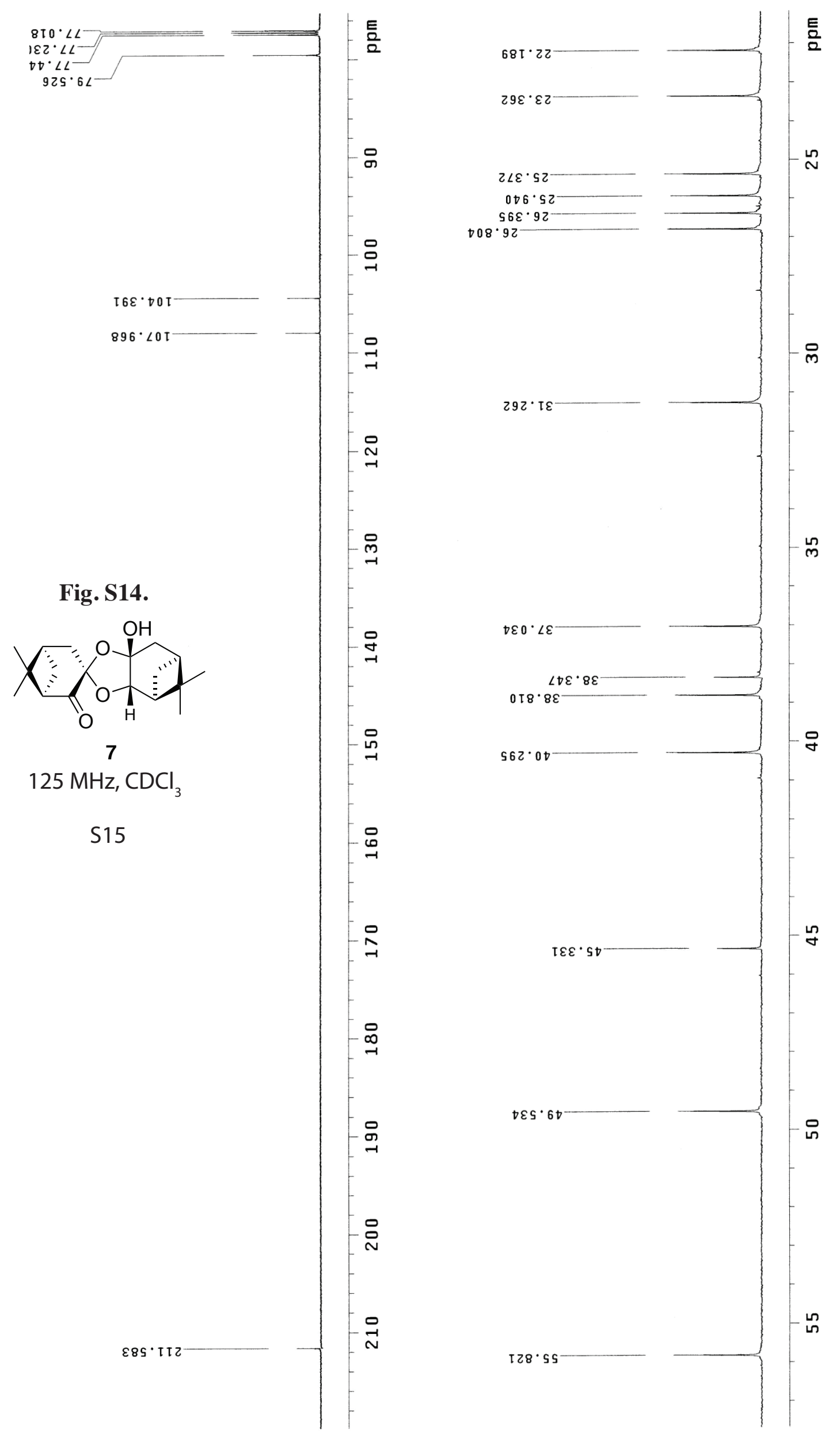


Fig. S15.

$X$

7

$125 \mathrm{MHz}, \mathrm{CDCl}_{3}$

$\mathrm{CH}_{3}$
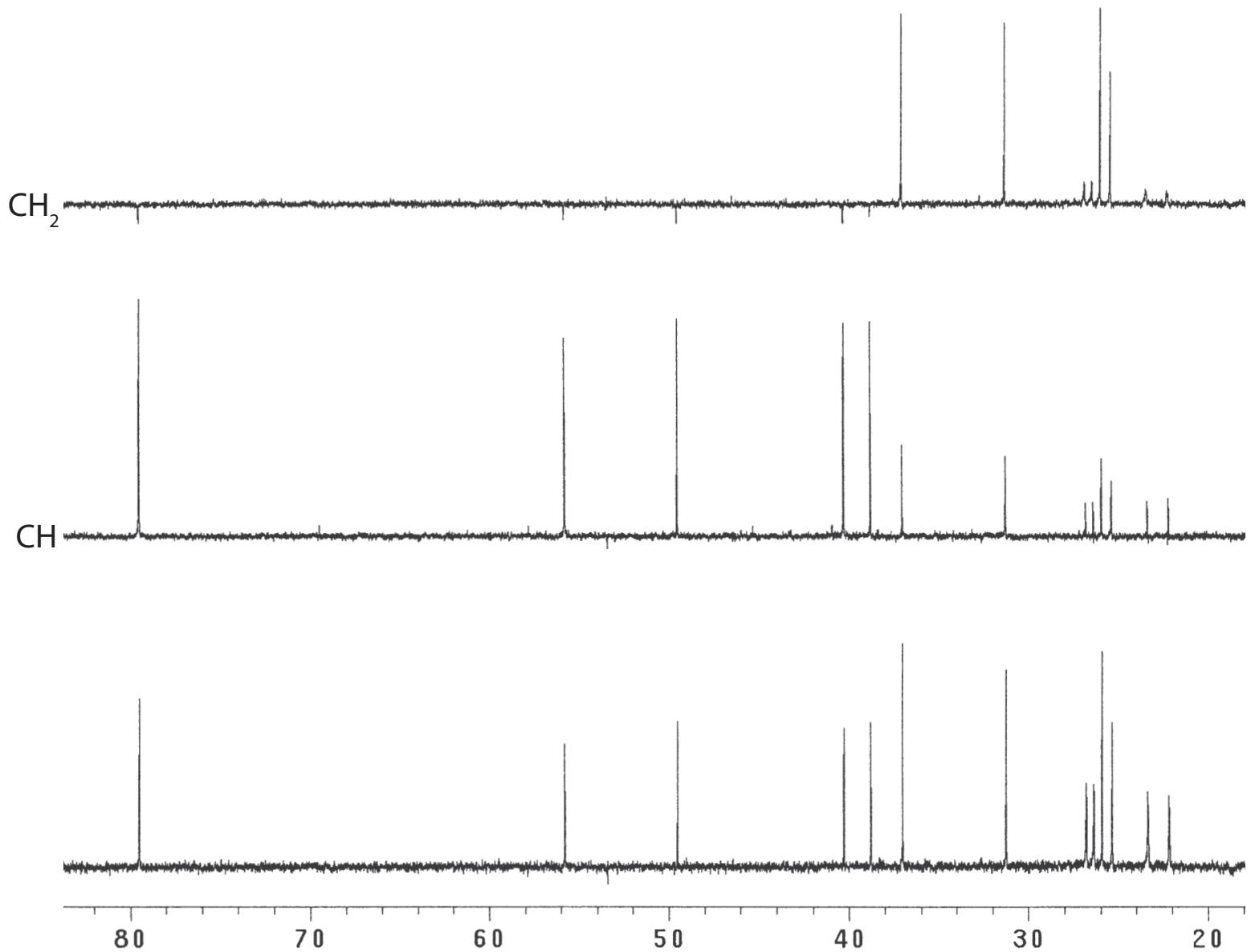

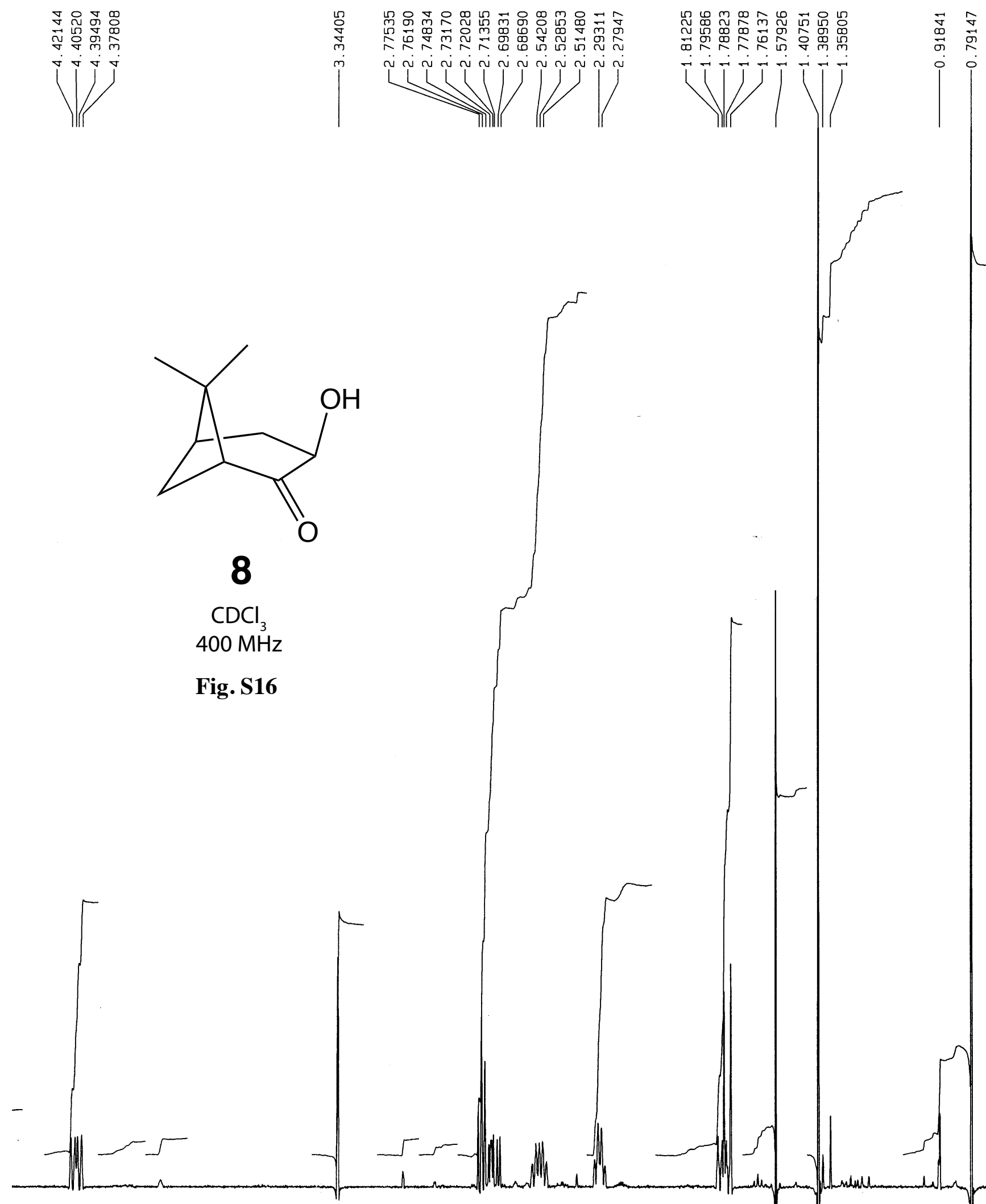

Fig. S16

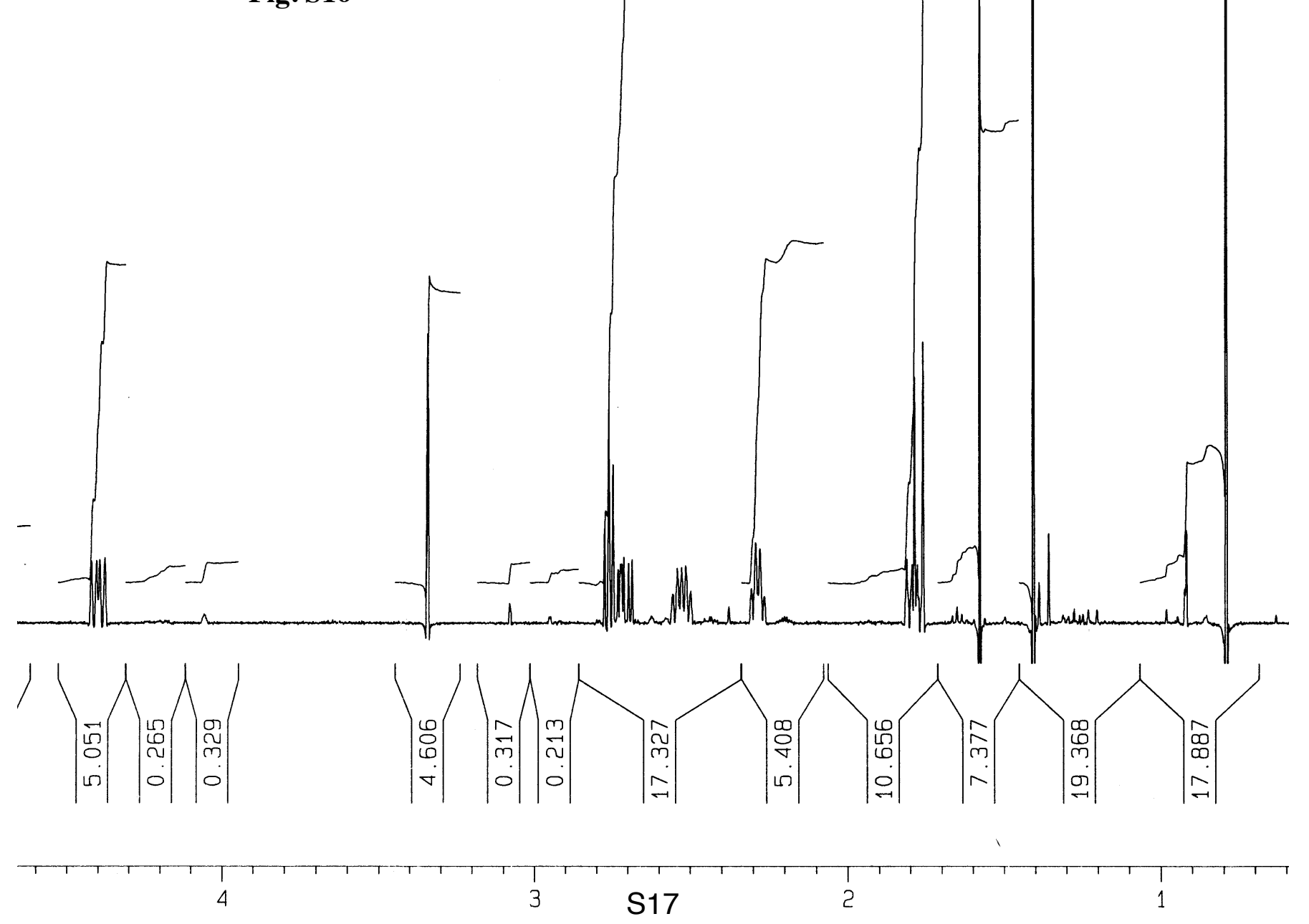


Fig. S17.
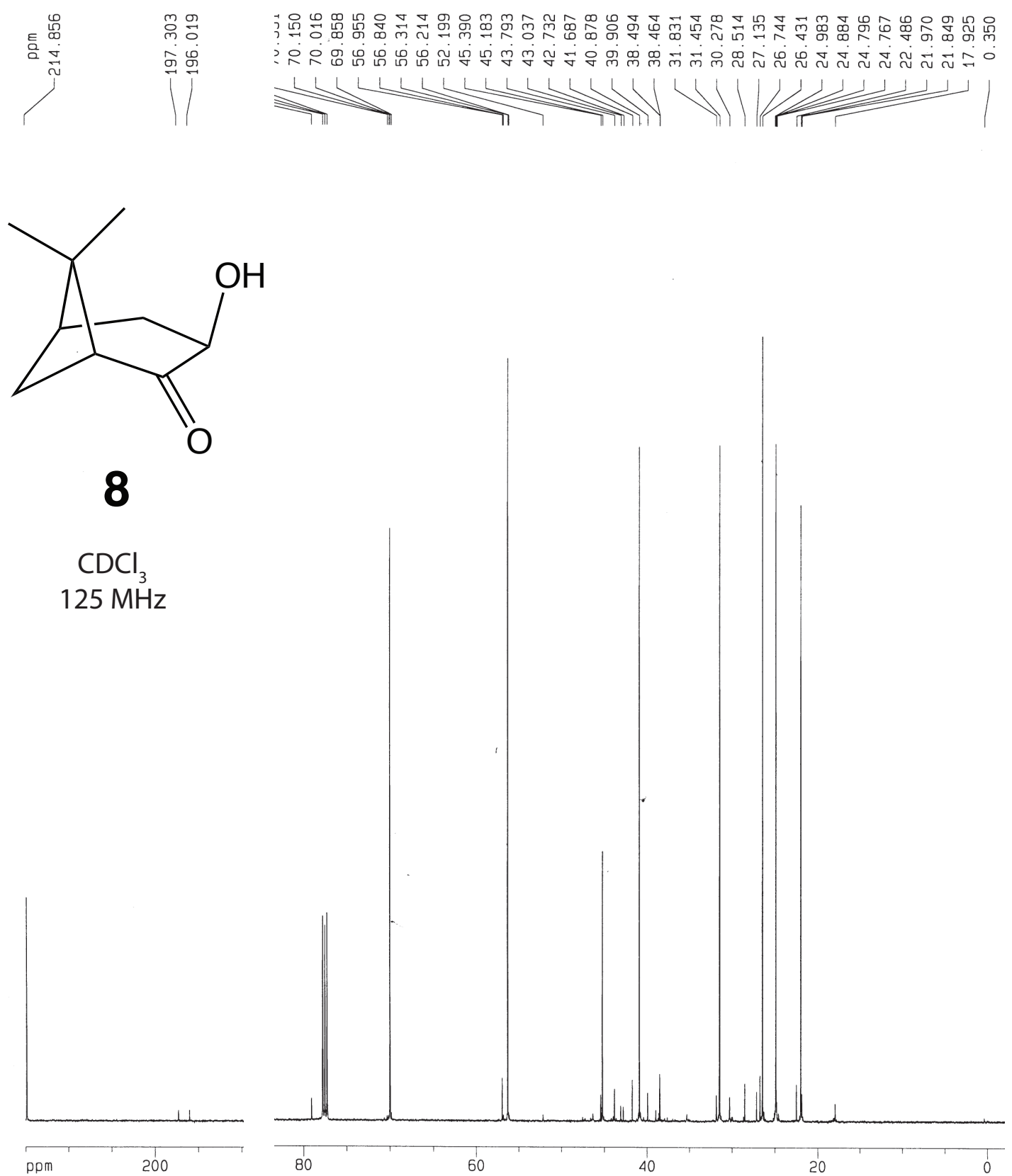